\title{
US Clean Energy Transition and Implications for Geopolitics
}

\author{
Jonathan Elkind
}

\section{Introduction}

The impacts of climate change pose severe challenges around the globe: rising sea levels, disrupted precipitation patterns, altered agricultural conditions, increasingly frequent droughts, brutal heat waves, and severe storms to name a few. Different regions of the United States will encounter all these impacts, just as is true elsewhere around our globe. Consequently, those Americans whose livelihoods or homes are vulnerable to a changing climate, and especially those who do not share in the country's overall prosperity, are at risk.

In addition, however, there is another form of risk that climate change poses for the United States: geopolitical risk. This country has been central to historical emissions of greenhouse gases and is today the world's second-greatest emitter of greenhouse gases. It is no less central to the global efforts to refine climate science and develop climate solutions, but it is preoccupied by a bitter, protracted debate over current and future climate policy.

So precisely when scientists and citizens around the globe are calling for an accelerated and scaled-up response to global warming, national leaders in the United States are profoundly divided over whether and how to contribute to climate solutions. Some Americans-especially policy-makers in leading states and municipalities and executives in an increasing number of companies-see climate as an existential challenge that requires a local, regional, national, and global response. These leaders intend for the United States to be part of the global solution. Others-especially Federal officials during the Trump Administration and many leaders in one of the two major U.S. political parties-view climate with disdain and are abdicating the country's duty to respond.

Already, this conflicted stance is causing damage to U.S. geopolitical interests. In the coming period, either the United States will return to playing a proactive and

\footnotetext{
J. Elkind ( $\varangle)$

Center on Global Energy Policy, Columbia University, New York, NY, USA

e-mail: jhe36@columbia.edu 
constructive role on climate change mitigation, or its influence and key relationships with partners around the globe will suffer serious harm. This chapter reviews the complicated and internally contradictory U.S. attitudes about the clean energy transition from the perspective of debates, bottlenecks, and progress occurring at the Federal, state, and municipal levels. ${ }^{1}$ It then assesses the implications of the climate issue for the geopolitical interests of the United States.

\section{U.S. Climate Policy: Struggling for Speed, Scale, and Durability}

Many policy analysts have referred to climate change as a "wicked problem"-a challenge of extraordinary complexity that defies easy resolution (APSC 2007). This rubric fits the climate challenge well because responding to climate change requires policies with a highly unusual combination of attributes that exist in tension with one another. This reality has greatly complicated the American response to climate for years, and especially in the last decade.

Success in responding to climate change requires policies that combine (a) speed, (b) scale, and (c) durability. The first part of the puzzle-speed-is easy to grasp for anyone who accepts the findings of the vast majority of the international scientific community: Atmospheric concentrations of greenhouse gases (GHGs) are rising due to human activity, and these concentrations are causing unprecedented changes in the global climate. Climate science is far from simple, and important uncertainties remain, especially in regard to regional climate impacts over the medium and long terms. But as successive analyses from the UN's Intergovernmental Panel on Climate Change and other authoritative sources such as the US National Academies of Science, Engineering, and Medicine have repeatedly documented, human beings are changing the climate by engaging in activities that result in GHG emissions, chiefly through energy-sector emissions of carbon dioxide (IPCC 2018; McNutt et al. 2019). ${ }^{2}$ Responding quickly is clearly a necessity for successful climate policy.

\footnotetext{
${ }^{1}$ The Federal government of the United States formulates national-level policy and legislation. Throughout this chapter, the terms Federal and national are often used synonymously.

${ }^{2}$ The IPCC's most recent assessment, which examined the implications of an effort to limit aggregate temperature rise to $1.5^{\circ} \mathrm{C}$, garnered a great deal of public attention around the globe because it stated starkly the necessity of urgent changes, starting immediately, especially in regard to the global energy economy (IPCC 2018). No less noteworthy was a short press statement, issued seemingly out of the blue by the presidents of the US National Academies in mid-2019. It reiterated the conclusions of the Academies' repeated climate assessments. The fact that the Academies' presidents felt it important to issue such a reiteration is itself testimony to the sense of alarm that the U.S. scientific community feels in light of policy-makers' seeming inability to take action on climate change. The statement read in part: "Scientists have known for some time, from multiple lines of evidence, that humans are changing Earth's climate, primarily through greenhouse gas emissions. The evidence on the impacts of climate change is also clear and growing. The atmosphere and the Earth's oceans are warming, the magnitude and frequency of certain extreme events are increasing, and sea level is rising along our coasts." (McNutt et al. 2019).
} 
A second required attribute is scale. No climate solution can be successful alone if it only addresses a narrow slice of total global greenhouse emissions. This is true in the case of sector-specific emissions reductions that are not accompanied by other, parallel measures addressing other sources of emissions. In the United States, as we will see shortly, laudable emissions reductions have occurred in the electric power sector, but they are insufficient because they have not been matched in sectors such as industry and transportation. It is equally insufficient to apply approaches that address emissions in one set of countries without also addressing emissions elsewhere. The risk of simply "exporting" emissions by creating incentives for industrial activity (and thus employment) to move off-shore has historically been a sensitive and often legitimate argument used by certain policy advocates in the United States and elsewhere who worry that poorly designed climate policies could harm national economies without meaningfully reducing emissions. The growth of U.S. oil and natural gas production over the past decade creates new complexity in regard to concerns over causing emissions to move to other countries.

A third necessary attribute is durability. Barring surprises in climate science, the business of building and sustaining climate-friendly economies must become an indefinite part of our global future. We need to become so skilled and effective at climate mitigation that we can maintain our level of effort without flagging. Indeed, over time we may need to respond to climate change with progressively more robust and far-reaching measures. We will not succeed in this effort if citizens feel that their quality of life is suffering unduly, or more than their neighbors. We must find solutions that will be durable over time, solutions that will not fall victim to popular backlash the next time we have an economic downturn.

Here it is worthwhile to flag the fact that some policy prescriptions for mitigating global warming could translate into major socioeconomic impacts. For example, some environmental advocates argue in regard to fossil fuel production that the United States should "leave it in the ground," and should in fact end fossil fuel consumption before the year 2030. But the oil and gas industries currently employ over 1.4 million Americans (NASEO-EFI 2019). This does not mean that the United States should fail to respond to the climate challenge in a timely and effective manner. Nor should one forget that the low- and no-carbon energy economy is resulting in the creation of many new jobs across the country. But the new clean energy jobs do not magically appear just where old jobs are being lost, and they do not always require the same skillsets that oil and gas workers have. These facts underscore the need for policies that adequately account for the impacts on hundreds of thousands of people's livelihoods. Most of those same people are voters; for the chosen climate policies to be durable, they must account for near-term negative socioeconomic impacts; the policies must provide for what many have come to refer to as a "just transition."

Adding to the complexity of this triple challenge is the fact that is not easy to implement policies and measures that simultaneously deliver speed, scale, and durability. For example, as will be discussed in greater detail below, twenty-nine of the fifty US states have found it to be comparatively straightforward to institute renewable portfolio standards (RPSs) that prescribe greater and greater shares of non-emitting wind and solar power in the electricity resource mix. An RPS can thus be implemented 
on a relatively speedy timeframe, and RPSs seem relatively durable in that many consumers express support for clean energy. But, important though these standards may be as early wins for avoiding GHG emissions, they will prove insufficient to respond to the totality of climate change because they fall short on scale; currentlyavailable and currently foreseeable renewable power technologies do not address emissions from certain hard-to-abate sectors such as steel, cement, or heavy-duty transport (especially by air and sea). ${ }^{3}$

Other policy approaches might in theory deliver speed and scale but fail to offer durability. After the protracted and unsuccessful attempt to enact a cap-and-trade system during President Obama's first term in office, and after his Republican political opponents made clear that they intended to oppose almost any Obama proposals in order to handicap him politically, the Obama Administration concluded that there was no chance of securing bipartisan legislative compromises to enable progress on climate-one of Obama's highest policy priorities. His Administration chose instead to implement policies that they felt could be based on existing legal authority. Thus, the Obama Clean Power Plan (CPP), which aimed to reduce power-sector emissions (discussed more below), was implemented pursuant to authority in the Clean Air Act. For the Obama team, this choice to opt for comparative speed seemed like the only path forward at the time. Unfortunately, the U.S. Supreme Court later suspended implementation of the CPP because of questions about whether the particular requirements under the Plan exceeded Clean Air Act authorities. And when Obama was succeeded by Donald Trump, the new U.S. Administration set about an extensive effort to dismantle the Clean Power Plan as well as many other Obama climate initiatives (Adler 2019).

Lastly, other policy prescriptions can excel in terms of their scale and perhaps even durability, but they face a significant challenge in terms of the speed with which they can be enacted. Arguably the classic example of this dynamic is the longstanding effort to introduce an economy-wide price on U.S. carbon emissions. If designed well, such an instrument could exert broad and powerful pressure to reduce greenhouse gas emissions with modest energy price impacts. ${ }^{4}$ And indeed, more US Members of Congress and policy advisors are currently expressing support for carbon pricing than at any time in recent memory. Nonetheless, the politics surrounding a carbon tax and other pricing mechanisms are especially daunting in the United States because of the country's almost legendary opposition to taxes. Few

\footnotetext{
${ }^{3}$ A possible exception to this statement about the difficulty of using renewables to address hard-toabate sectors could be solutions like so-called "green hydrogen"- -where renewable power sources are employed to electrolyze water and produce hydrogen. Whether green hydrogen can, over the medium term, prove to be a commercially viable options remains to be seen.

${ }^{4}$ Colleagues at the Center on Global Energy Policy, led by Dr. Noah Kaufman, have undertaken important work assessing potential design tradeoffs and implications of a carbon tax at the Federal level in the United States. Their analysis examines the emissions reductions that could be achieved with different levels of a tax, designed in different ways, as well as the macroeconomic, fiscal, and distributional impacts of potential carbon taxes. Their work makes clear that if a well-designed carbon tax could be instituted, it could be a powerful incentive for emissions reductions and could even reduce energy expenditures of many households, including less-affluent households (Kaufman and Gordon 2018).
} 
analysts expect that any meaningful carbon pricing mechanism will be instituted under the Trump Administration. Carbon pricing's potential strengths in terms of scale and durability thus are not matched in terms of speed.

With this understanding of the importance and challenge of implementing climate solutions that integrate speed, scale, and durability, let us now examine the status and main trends of the clean energy transition in the United States.

\section{Headline Trends in the U.S. Clean Energy Transition}

At present, the United States is the world's second-largest emitter of greenhouse gases. The U.S. energy sector represents more than $80 \%$ of total U.S. greenhouse gas emissions. Consequently, the country's success in executing the transition to clean energy has massive implications for the success of the global response to climate change.

Over most of the past decade, the United States has recorded mixed results on the transition to clean energy. The progress that has occurred has largely been in the electric power industry, and largely thanks to energy market developments and technological advances. Policy at the national level and macroeconomics have each played contradictory roles over this same timeframe, with some years when they contributed to clean energy progress and other times when they led to retrenchment. State-level and municipal policies, however, have played a progressive and important role, as we will discuss below.

The electric power sector has achieved the greatest clean energy results. That sector represented nearly $80 \%$ of total reductions in U.S. greenhouse gas emissions from 2008 through 2017, with its $\mathrm{CO}_{2}$ emissions dropping by more than $25 \%$, from 2.4 to 1.8 gigatonnes (EIA 2019a). After decades as the leading sectoral source of greenhouse gas emissions, the power sector fell to second position, with emissions lower than those from the transportation sector, as shown in Fig. 1. The greatest contributing factors for this change have been fuel-switching from coal to natural gas $^{5}$ and, more recently, the growth of investments in solar and wind energy, the results of which can be seen in both the precipitous drop-off in coal consumption shown in Fig. 2 and the decrease in power generation from coal in Fig. 3.

The industrial sector, which represents slightly more than one-fifth of total U.S. greenhouse gas emissions, saw sustained improvements in recent years in the clean energy transition, but that trend appears now to have halted. Industrial emissions of carbon dioxide fell by $22 \%$ over the two decades from 1997 to 2018 , from 1.8 to 1.4

\footnotetext{
${ }^{5}$ The emissions reductions resulting from coal-to-gas fuel-switching are the subject of ongoing debate in the expert community. Some peer-reviewed analysis suggests that standard methods for estimating leakage of methane in the oil and gas supply chain are significantly underestimating actual leakage rates. See, for example, Alvarez et al. (2018). Particularly for United States, where increased production and power-sector consumption of natural gas have been such an important feature of recent years, accurate understanding of methane leakage rates will play a vital part in evaluating true emissions rates and emissions reductions.
} 


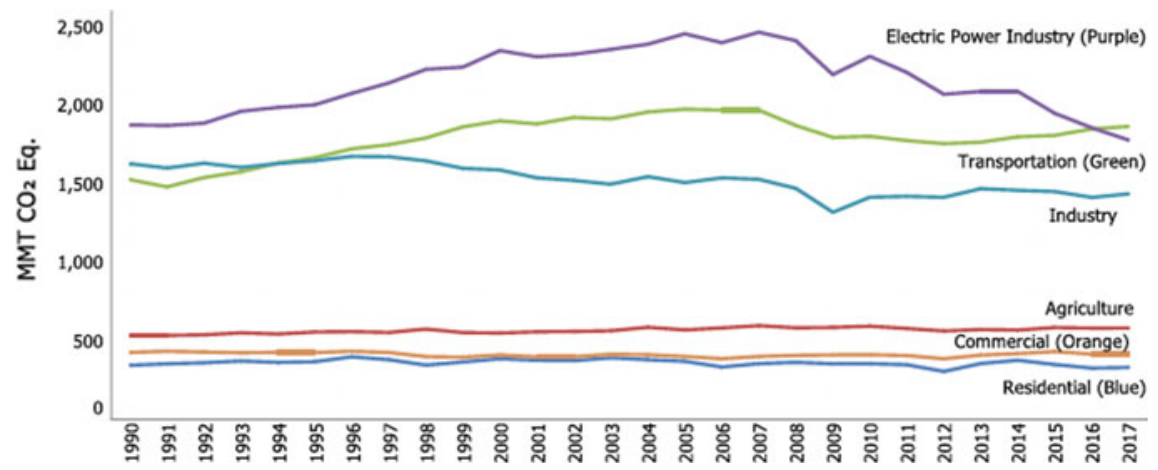

Fig. 1 U.S. greenhouse gas emissions by sector. U.S. Environmental Protection Agency (EPA 2019a)

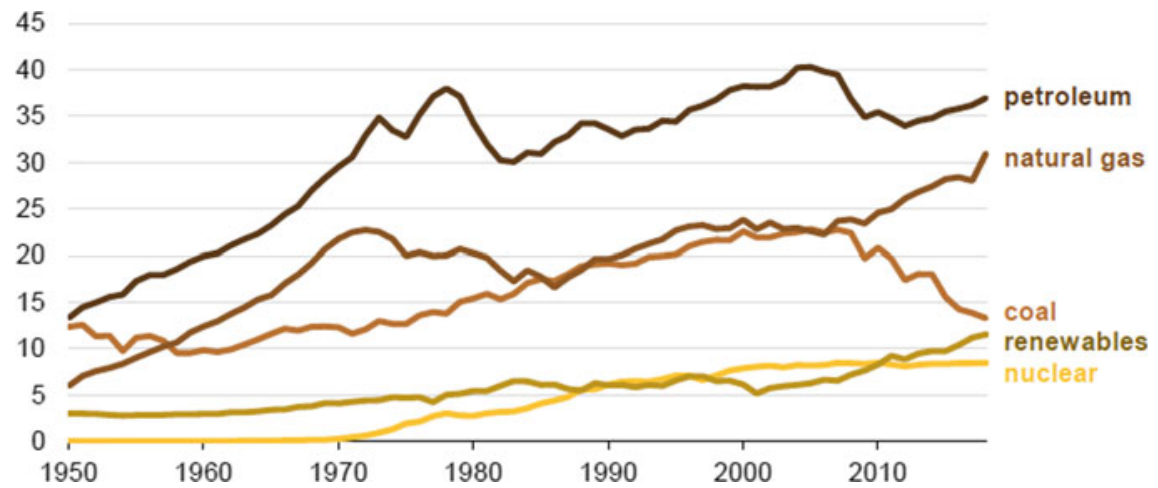

Fig. 2 U.S. total energy consumption by fuel (1950-2018) in quadrillion Btus. Energy Information Administration (EIA 2019b)

gigatonnes. Changes in energy-related industrial emissions over that period reflected, among other factors, overall economic activity, structural features in American industry (e.g., shares of energy-intensive industries in the overall mix), and technologies employed in energy-intensive industries (such as the adoption of higher efficiency technologies for heavy energy consumers like steel-making).

The residential and commercial sectors, which together represent just less than $30 \%$ of total greenhouse gas emissions (roughly 15\% from residential, $14 \%$ from commercial), have held reasonably steady over the past decade. Key factors in these sectors' energy consumption and GHG emissions levels have been weather-related parameters, translating into the number of heating- and cooling-degree-days, and the efficiency of household equipment and appliances, which has improved steadily (EIA 2019b).

The sector that has been most clearly moving backward in terms of greenhouse gas emissions is transportation. This sector is an especially important bellwether for 


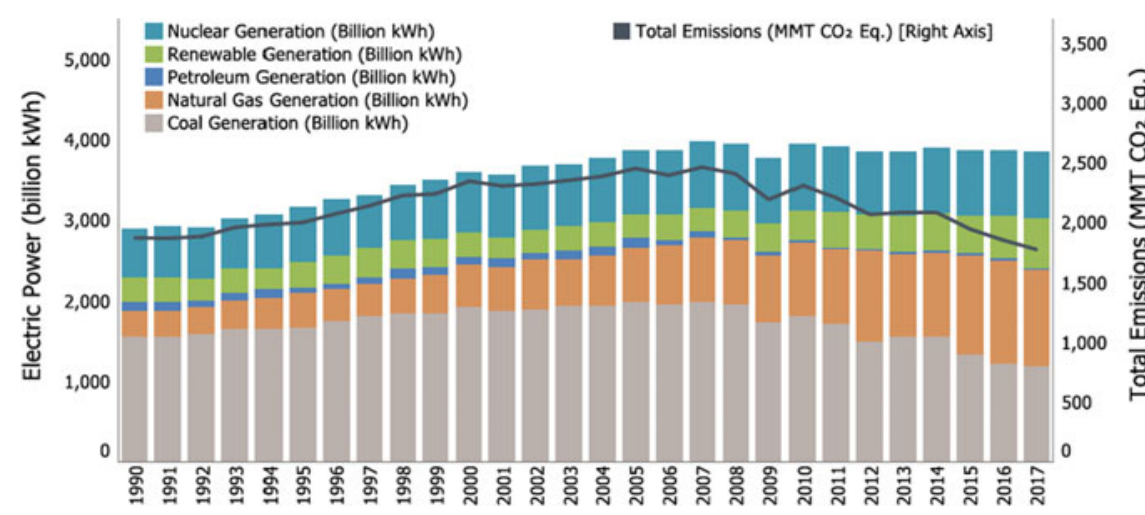

Fig. 3 Electric power generation (Billion $\mathrm{kWh}$ ) and emissions (MMT $\mathrm{CO}_{2}$ Eq.). U.S. Environmental Protection Agency (EPA 2019a)

progress in the U.S. clean energy transition, as transportation represents over $70 \%$ of U.S. petroleum consumption and nearly $29 \%$ of total energy use (EIA 2018). For each year since 2012, transportation emissions have grown (EIA 2018), and transportation has surpassed electric power as the single largest source for greenhouse gas emissions by sector.

Whether transportation demand and emissions will continue to grow is a critical component of the future U.S. clean energy transition. Since 2004, the efficiency of the U.S. road vehicle fleet has increased steadily, with light-duty vehicle efficiency improving by $29 \%$ over that period and $\mathrm{CO}_{2}$ emissions per mile dropping by $23 \%$ (EPA 2018). The improvement since 2004 has been undercut, however, by increases in fuel demand for aviation and freight vehicles (Houser et al. 2018) and increases in the amount of vehicle-miles-traveled (VMTs) for light-duty vehicles, which grew by 49\% over the period from 1990 to 2017 (FHWA 2018). VMT increases in turn reflect a variety of factors, including population growth, overall economic growth, land-use patterns (especially urban sprawl), and consumer responses to low fuel prices (EPA 2019a). The Trump Administration announced its intention to freeze increases in vehicle efficiency requirements under the Corporate Average Fuel Economy (CAFÉ) standards, a proposal that is still being reviewed as of this writing, discussed in more detail below.

One transportation trend that holds the promise of reduced GHG emissions is the electrification of the light-duty vehicle fleet. After years of only gradual sales growth, and total numbers amounting to less than one percent of the total vehicle fleet on the road, electric vehicle (EV) purchases boomed in 2018. Sales grew by more than an $80 \%$ increase to bring the total fleet to over 360,000 EVs (Pyper 2019). EVs are not yet of sufficient scale to materially alter the emissions profile of the transportation sector in the near term, but they may now be gathering momentum with car buyers. 


\section{Federal Policy for Clean Energy}

Having surveyed the major trendlines in the U.S. clean energy transition-trendlines that are far from uniformly encouraging-we now turn to a discussion of policy at the Federal, state, and local levels. One finds a country whose Federal-level leaders have struggled to reach consensus on what constitutes effective policy with regard to climate change and the clean energy transition. Indeed, political leadership in the United States splits into those who are convinced that we need an urgent and broad response, and those who say they see no problem to respond to.

During the past decade and a half, the U.S. Federal government has played a variety of roles in regard to the clean energy transition. The first U.S. president in this century, President George W. Bush, did not prioritize policies intended to spur reductions in greenhouse gas emissions. The Bush Administration did, however, sustain strong investments in scientific understanding of the global climate system, which have been a foundational part of U.S. Federal policy since the administration of his father, George H.W. Bush. Moreover, through both policy and legislation, the George W. Bush Administration gave prominent emphasis to energy research and development, much of it targeting clean energy $R \& D$.

From the very start of President Barack Obama's term in office in January 2009, his Administration signaled that it saw climate change as a top policy priority. President Obama described climate change as one of the defining challenges of the current age, a moral threat imperiling the future of humanity. In his first term, Obama included funding of more than $\$ 90$ billion for the deployment of clean energy technologies in the American Recovery and Reinvestment Act, which the U.S. Congress passed in response to the 2008 financial crisis (White House 2016a). Obama also tried but failed to pass economy-wide legislation sponsored by Democratic Representatives Henry Waxman of California and Edward Markey of Massachusetts that would have capped emissions of greenhouse gases from the power sector and many other industrial sources and established a trading system for GHG emission reductions (CBO 2009). The failure of the Waxman-Markey cap-and-trade measure was a bitter defeat. In its wake, the Obama Administration sought during its second term to respond to climate and the clean energy transition by taking actions based on its interpretation of existing legal authority.

The centerpiece of this executive action was President Obama's Climate Action Plan (CAP), released in June 2013 (White House 2013). CAP called for a portfolio of actions aimed at reducing U.S. greenhouse gas emissions and increasing the country's preparedness for the impacts of climate change, plus enhanced collaborations with key international partners. The single most significant element of CAP in terms of projected emissions reductions was its instruction to the Environmental Protection Agency (EPA) to promulgate new regulations to limit greenhouse gas emissions from electricity generating plants. The Clean Power Plan (CPP), as this new program of regulations came to be known, called for newly built and existing power plants to emit less than prescribed maximum levels of $\mathrm{CO}_{2}$ per unit of output. During the CPP's development, the plan was expected to drive retirements of subcritical coal plants and older, inefficient gas-fired plants. 
In reality, two considerations emerged that meant that CPP never lived up to the Obama team's expectations. First, many utility companies were opting to retire those high-emitting coal plants anyway, and even faster than the CPP required. Local pollution requirements (such as those limiting emissions of mercury), favorable economics for high-efficiency natural gas plants, and plummeting costs for solar or wind power plants meant that coal plants were increasingly unattractive for utilities. Moreover, twenty-seven states introduced legal challenges to the CPP, and the Supreme Court temporarily "stayed" (or halted) the CPP's legal implementation. When President Trump came into office, his Department of Justice announced that it would not proceed with a legal appeal against the stay. In June 2019, Trump's EPA issued a much weaker proposal, the so-called Affordable Clean Energy (ACE) rule, which called for improvements in the operating efficiency of remaining coal plants, but which was projected by many analysts to have no discernible impact on reducing power-sector GHG emissions. The ACE rule was immediately challenged in court (Friedman 2019).

Another major component of the Obama CAP was a concerted focus on the energy efficiency of vehicles, buildings, appliances, and equipment. CAP called for the promulgation by the U.S. Department of Energy of new appliance and equipment standards that would, by 2030, result in a cumulative total of three billion tonnes of avoided $\mathrm{CO}_{2}$ emissions. CAP also focused on transportation-related greenhouse gas emissions - through the first-ever efficiency standards for heavy-duty vehicles as a complement to the Corporate Average Fuel Economy (CAFÉ) increases that the Obama Administration had set in place during its first term, and also through research and communications that would facilitate the adoption of electric vehicles.

CAP also set in motion new efforts to assess and reduce the leakage of methane from both energy- and non-energy-related sources. A final energy-related aspect of CAP was its call for extensive international leadership by agencies of the U.S. Federal government, including through mechanisms such as the Clean Energy Ministerial and collaborative bilateral research efforts with China, India, and other key partners.

The Obama Administration pledged through its Nationally Determined Contribution (NDC) under the Paris climate agreement to reduce its greenhouse gas emissions by $26-28 \%$ by 2025 , using a 2005 baseline. The Obama Administration also recognized that the goal of protecting the global climate would require far greater, sustained reductions in greenhouse gas emissions. For this reason, the Obama Administration prepared, and formally submitted at COP-22 in Marrakech in November 2016, the U.S. Mid-Century Strategy for Deep Decarbonization. The Mid-Century Strategy proposed to extend out to mid-century the downward-sloping emission trajectory started by the $26-28 \%$ reductions of the U.S. NDC and indicated the kinds of changes that would be necessary to achieve deep decarbonization by 2050 (White House 2016b).

The Mid-Century Strategy was announced after the 2016 presidential election, and it was already clear from statements of the incoming President that the new Administration was likely to think very differently about climate change and the role of Federal policy in responding to it. President Donald Trump came into office pledging to remove regulatory burdens from American business, even regulations 
intended to protect the environment or public health. Trump appointed as key members of his initial cabinet and sub-cabinet people who had long histories as climate skeptics—-such as Scott Pruitt, Trump's initial Administrator of the U.S. Environmental Protection Agency. Obama's sense of urgency about climate-his call to answer a moral struggle-was long gone. The United States now had a president who, as a candidate, had referred to climate change as a hoax.

In numerous public remarks and Congressional hearings, Administration officials called into question the science of climate change (Gustin 2018). Administration officials and the President himself repeatedly accused his predecessor of engaging in a "war on coal." The Trump team pledged to "end the bureaucratic blockade" that they accused the previous Administration of creating. They promised to put miners back to work across the United States (Perry et al. 2017). In June 2017, the President announced his intention to withdraw the United States from the Paris climate agreement. ${ }^{6}$

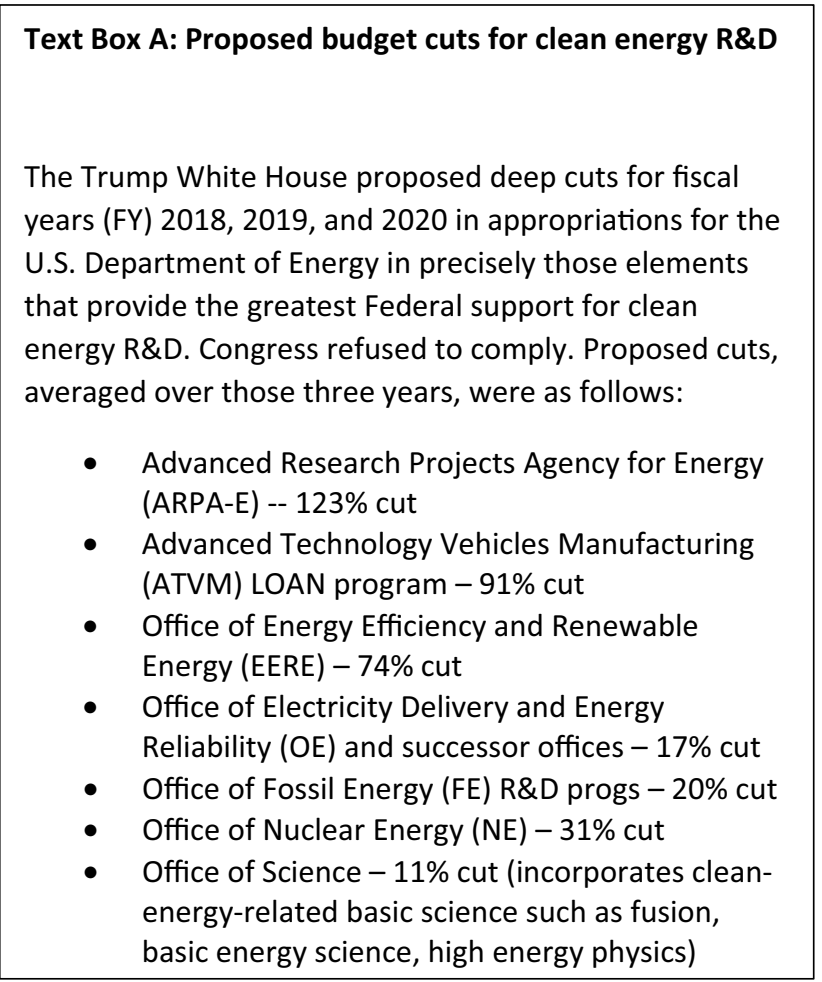

\footnotetext{
${ }^{6}$ It is important to note that President Trump announced his intention to withdraw the United States from the Paris climate agreement, but contrary to many assertions, the United States has not yet withdrawn from the Paris agreement. Trump's intention can only be fulfilled, in accordance with the terms of the agreement, after the elapsing of a prescribed amount of time. This means that the actual withdrawal cannot occur until the day after the 2020 U.S. election. Until that time, U.S. negotiators continue participating in meetings occurring under the terms of the Paris agreement.
} 
Trump Administration spokespeople summed up their energy policy as the promotion of "energy dominance." Like many political slogans, the practical meaning of "energy dominance" never came to be crisply defined. What was clear was that the Trump Administration favored a production-oriented, export-oriented approach to energy policies - one where environmental protection was more likely to be treated as an unwelcome hindrance than an essential building block.

As part of the Trump de-regulatory agenda, the new Administration set about dismantling many of the policies that the Obama team had used to create incentives for the clean energy transition. EPA Administrator Pruitt halted the implementation of the Clean Power Plan and set in motion a re-writing of vehicle efficiency standards. Pruitt also announced the intention not to implement new rules on methane leakage, a move that was quickly rejected by the courts.

In reality, removing regulations is not as simple as some in the Trump Administration may have wanted for people to think. The Administrative Procedures Act requires that new regulations be justified by benefit-cost analysis and be enacted only after public notice-and-comment procedures. The same strictures apply when one is removing existing regulations; the action must be justified by benefit-cost analysis and must undergo notice-and-comment. Many of the de-regulatory "victories" trumpeted by the Trump Administration were therefore premature claims (Adler 2019).

Another feature of Federal policy on clean energy under President Trump has been his selective - and climate-unfriendly_-budget-cutting agenda. Here, the President persistently sought to cut parts of the Federal budget that would facilitate the clean energy transition-programs aimed at deployment of current technologies and those focused on development of the next generation of technologies. Text Box A presents the average funding reductions (in percentage terms) that the Trump White House requested in its first three budget proposals. Both from the Administration's persistence and from its public comments, the Trump team made clear that these proposed cuts reflected the Administration's broader hostility toward engaging on climate change. For example, in presenting Trump's first budget request to the press in March 2017, then-budget director Mick Mulvaney dismissed the notion of funding for climate-related research: "We're not spending money on that anymore. We consider that to be a waste of your money" (Phillip 2017).

Under the U.S. constitution, however, the Executive Branch does not have unilateral decision-making authority regarding the Federal budget. The White House proposes each fiscal year's budget to Congress; the Legislative Branch then develops and passes appropriation bills. Generally speaking, enacted budgets substantially reflect Congressional priorities - not simply those of the White House. The President can, theoretically, veto Congressional spending bills, but doing so can alienate members of the President's own party. Once the budget is signed and enacted, it must be implemented by the Executive Branch. Congressional decision-making is often motivated in part by funding for institutions in Congressional members' home districts, and consequently most clean energy R\&D budgets have actually grown over the years since President Trump came into office (DOE 2017, 2018, 2019). 
One particularly positive development for Federal-level clean energy policy during Trump's tenure was the provision, in the Bipartisan Budget Agreement from February 2018, to expand the provisions of the so-called 45Q tax credits. The expanded tax credits were expected to provide meaningful incentives for the development of carbon capture, utilization, and sequestration (CCUS) projects. CCUS is viewed by many as a critical area for technological progress to enable a successful response to climate change.

If, as we have seen above, Federal policy on climate change suffered from pronounced political divisions in policy, an obvious question is whether the 2020 presidential election will bring more pendulum swings or perhaps a new national consensus on climate. It would certainly defy popular expectations to suggest that President Trump might relent in his hostility toward climate in the remaining months of his current term. And the current president can almost certainly be relied upon to veto most climate legislation-if indeed any such legislation could pass the Republican-led Senate and reach his desk. Nonetheless, starting after the 2018 midterm elections, members of both the President's own party and the Democratic opposition began spending an increasing amount of time considering policy options ranging from the mild to the ambitious. At a minimum, these options hint at the possibility of legislation that could pass the Congress and be placed before the next president, whether that is a second-term President Trump or a newly arriving Democrat.

Some of the main policy proposals that are circulating in the U.S. Congress and among other political leaders include these: First, a number of Republican members of Congress are exploring ideas to support clean energy innovation, often with support from Democratic counterparts. Many of these ideas are comparatively noncontroversial. Some focus on support for next-generation nuclear energy or CCUS technologies. Another and more hotly debated area of focus has been carbon pricing. A veritable who's-who of former Republican cabinet members and a number of noted Democrats, for example, have formed the Climate Leadership Council and called for the passage of a carbon tax. Notwithstanding vigorous opposition from the Republican Congressional leadership, one Republican representative, Carlos Curbelo of Florida, even proposed legislation for a carbon tax in the summer of 2018, only to be defeated by a Democratic opponent in the November 2018 midterm elections. Over fifty Democrats have signed on as joint sponsors of carbon tax legislation in the 2019 Congressional term, with very cautious Republican support, although the prospects for such proposals is highly uncertain.

Many observers partially attribute the new Congressional attention on climate policy proposals to the fact that the midterms delivered a new Democratic majority in the House of Representatives. With the Democrats' resulting ability to set legislative and hearing agendas, climate ideas that never saw the light of day under Republican control of the House of Representatives are now up for detailed debate.

Another factor that is sometimes credited for the renewed vigor in climate debates is the proposal known as the Green New Deal (GND). The GND is an expansive set of goals, advocated most prominently by first-term Representative Alexandria Ocasio-Cortez of New York. It calls broadly for (a) rapid and deep decarbonization accompanied by (b) employment guarantees in the clean energy sector, especially 
including minority and economically disadvantaged communities, (c) health care reform, and (d) measures to address local pollution problems that have beset many low-income minority populations. The GND was embodied first in a non-binding resolution that was passed by the Democratic-controlled House of Representatives in early 2019 (Congress 2019).

Despite the fact that the GND was not immediately translated into formal legislative proposals, and despite the fact that it served as a political pinata for President Trump and certain other Republican leaders, many of whom equated it to socialism, the GND seemed to alter the political playing field on climate and clean energy. It seemed to capture a growing sense of public concern about climate change-which is reflected in opinion polling especially among Democratic voters. Each Democratic presidential candidate was asked on the record whether she/he supported the GND. Widespread climate protests in numerous American cities (and in other cities worldwide) only intensified the pressure for accelerated climate action.

Republicans also felt forced to respond to the pressure created by public opinion and the GND. One Republican Representative, Matt Gaetz of Florida, proposed an alternative package entitled the Green Real Deal, which contained certain pro-climate measures but stripped out the GND's broader socioeconomic ambitions. Former Rep. Curbelo summarized the dynamic surrounding the GND by giving public credit to its proponents: If we Republicans do not like the Green New Deal's elements, he said, we will have to say what we as a party do support. ${ }^{7}$

\section{State-Level Policies for Clean Energy}

If Federal-level policy under the Trump Administration markedly moved away from focusing on the clean energy transition, and if the field of play on climate was confused and uncertain as the next presidential election approached, the same could not be said for the majority of states and a significant number of municipalities. Here one saw a mounting sentiment that responding to climate change is a policy priority.

A plurality of the 50 states - states with Democratic leaders as well as some with Republican leaders - banded together in a variety of formats and initiatives to reject very publicly the climate-hostile policies that have dominated the views of the Trump Administration. Some elected to put in place policies that create direct incentives to build low- or no-carbon energy systems or create indirect incentives to do so. Others pledged to reduce their state-level emissions to levels in keeping with the Obama-era pledge under the Paris climate agreement. Others laid out sweeping programs for deep decarbonization by mid-century.

\footnotetext{
${ }^{7}$ Curbelo's on-the-record comment was made in the course of a program on proposed climate solutions hosted by the Center on Global Energy Policy at Columbia University (CGEP 2019). For an excellent analysis of the Green New Deal and its significance in the debates about Federal climate policy, see Bordoff (2019).
} 


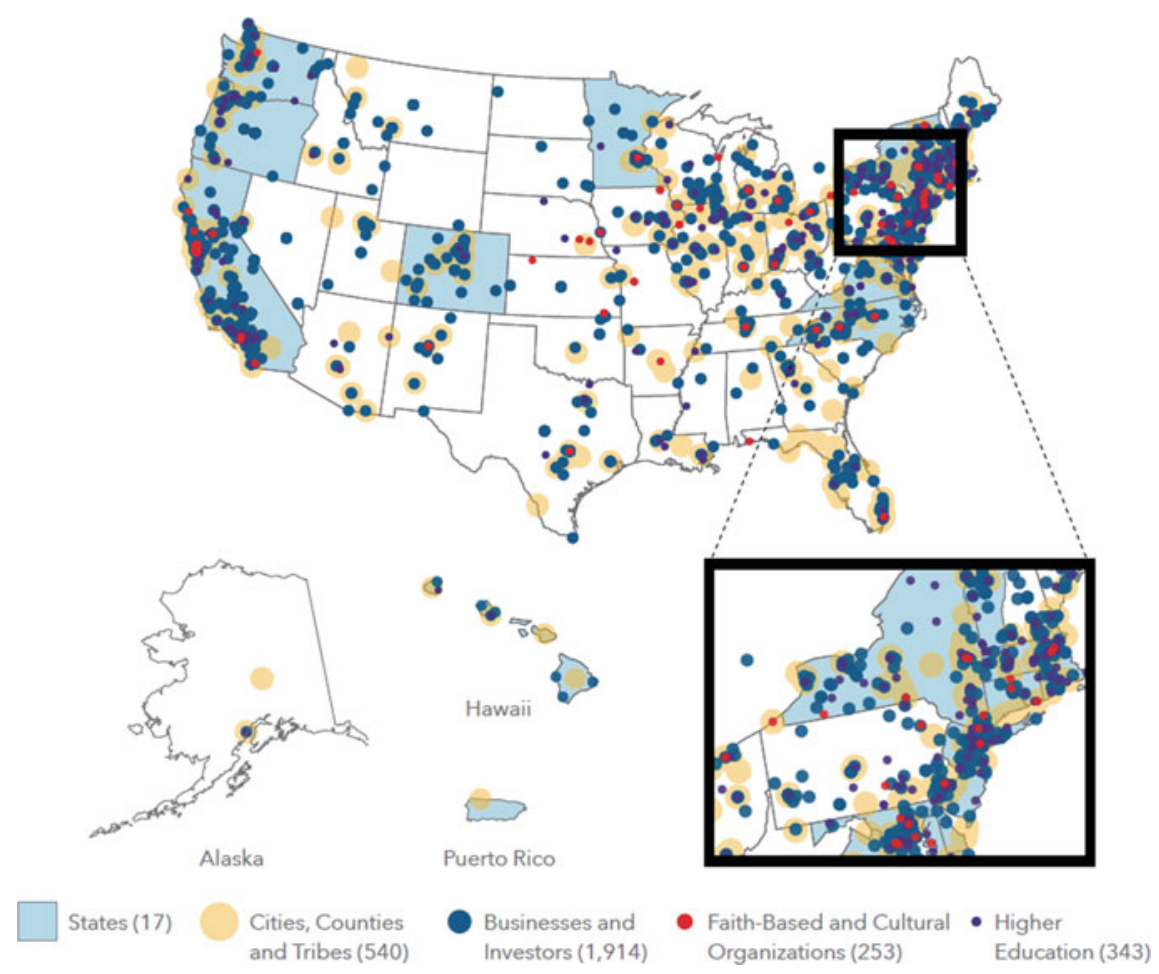

Fig. 4 States, cities, and other entities pledged to fulfill Paris pledge (as of 2018). America's Pledge (AP 2018)

President Trump's Rose Garden announcement in June 2017 that he intended to withdraw the United States from the Paris climate agreement triggered vociferous, public rejection by a number of governors. Most prominently and immediately, Governor Jerry Brown of California, Governor Andrew Cuomo of New York, and Governor Jay Inslee of Washington declared that their three states would adhere to the emissions reductions pledged in the Obama Administration's Paris pledge, and they called for others to join them.

Their grouping came to be referred to as the United States Climate Alliance. As of this writing it includes 25 states and one territory in its membership. The Climate Alliance thus represents $55 \%$ of the population of the United States, $40 \%$ of U.S. GHG emissions, and $60 \%$ of the total U.S. economy, or $\$ 11.7$ trillion on an annual basis (USCA 2019b). As can be seen in Fig. 4 (which is itself already dated since several additional states subsequently joined the Climate Alliance), the states, cities, and other entities pledging themselves to fulfill the Paris climate pledge are heavily_but not exclusively-clustered along the Atlantic and Pacific coasts with other concentrations in the industrial Midwest and a scattering of participants across the Plains states (AP 2018). 


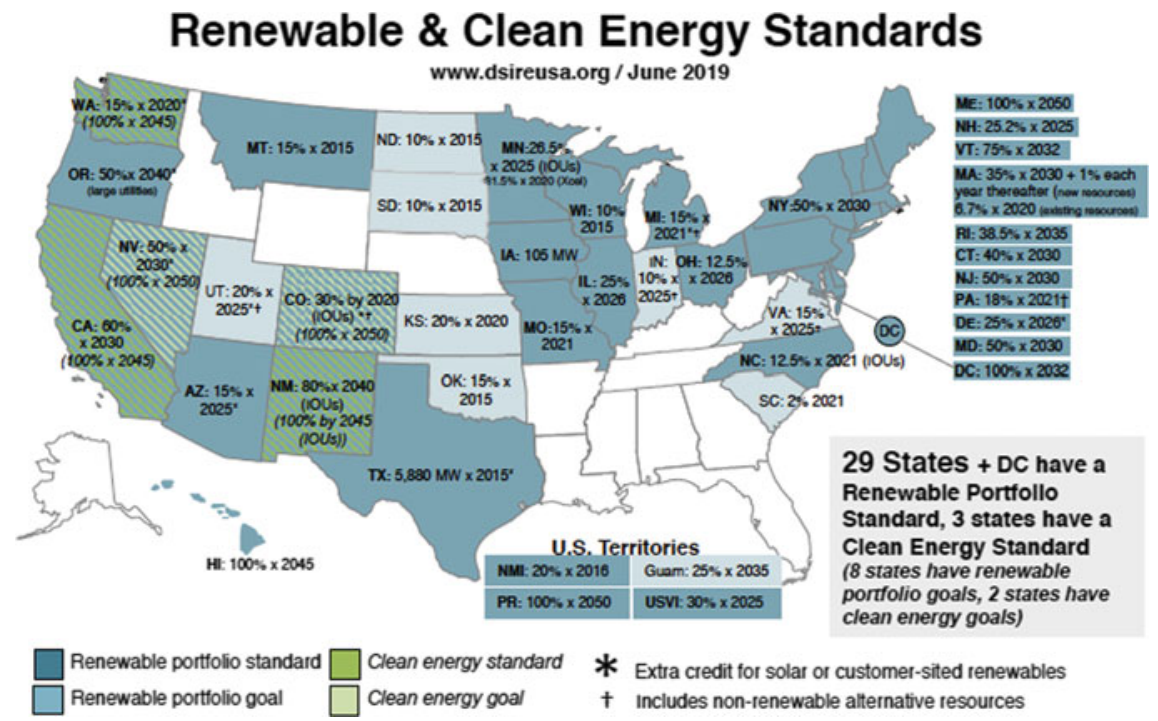

Fig. 5 States employing Renewable Portfolio Standards (RPSs) and Clean Energy Standards (CESs). Database of State Incentives for Renewables and Efficiency (DSIRE 2019)

The states participating in the Climate Alliance committed to reduce their emissions in a manner consistent with the Obama-era Nationally Determined Contribution-namely, by 26-28\% below 2005 levels by 2025 . They also committed to track and report their progress, to institute new policies to reduce carbon pollution and promote the clean energy transition, and to facilitate knowledge-sharing so that states can learn from each others' experience (USCA 2019b). The participating states represent a considerable mass: If collectively they formed a single national economy, they would rank third in the world, smaller than only the entire United States and China (USCA 2019a; AP 2018).

Arguably the single most visible state-level policy that has been used to incent deployment of clean energy is the renewables portfolio standard (RPS). RPSs apply to $56 \%$ of retail electricity sales nationwide (Barbose 2018). RPSs typically prescribe the share of total electricity sales that must come from renewable generation sources in the course of a year. Different states' RPSs are not uniform in scope, application, or rules, however, because they are developed under the authority of individual state governments and therefore respond to state-level politics, resource endowments, and policy priorities. Some apply to all electric utilities in the state; others apply only to investor-owned utilities but not to municipally-owned utilities or cooperatives (or perhaps they apply to munis and coops, but with less stringent requirements). Some have caps on the cost of the RPS. Some mandate the absolute amount of generating capacity rather than percentage share of retail sales coming from renewable energy generation (Barbose 2018).

As is shown in Fig. 5, a total of 29 of the 50 states in the union, plus the District of Columbia and three U.S. territories, now employ legally-binding RPSs. Many of 
these states have progressively increased the stringency of their standards in recent years as costs for wind and solar power dropped and concerns about climate change rose. In fact, in the decade from 2009 to 2018 alone, states elected to strengthen their RPSs on 65 occasions (some doing so more than once) (Barbose 2018). Seven states now have RPSs requiring utilities to generate $50 \%$ or greater shares from renewables (NCSL 2019). In addition, a growing number of states are instituting clean energy standards (CESs) - sometimes as an alternative structure to an RPS and sometimes as a complement thereto. Because CESs generally permit the use of other non-GHGemitting technologies such as nuclear power or natural gas paired with CCUS, CESs are expected to facilitate greater flexibility and thus greater cost control as states move toward higher levels of decarbonization.

The legal status of these RPS and CES programs varies. Some are simple policy goals; others are binding requirements from state-level utility commissions and still others are enforceable mandates enshrined in state-level law. The unmistakable trend toward progressively greater ambition is clear-including $100 \%$ carbon-free electricity in several states and net-zero-carbon entire economies in other states. ${ }^{8}$

Among these is California, which now has an RPS of $50 \%$ by 2026 , followed by a $60 \%$ RPS by 2030 , followed by a requirement of $100 \%$ net-zero-carbon electricity by 2045 . The latter step leaves open the use of clean generating resources other than wind or solar-namely, nuclear, or hydro-electric, or carbon capture and utilization or storage paired with either industrial installations or natural gas power generation. The legally binding timelines are also augmented by non-binding executive orders that call for (a) economy-wide carbon neutrality by 2045 plus (b) an economywide reduction of all GHG emissions by $80 \%$ below baseline by 2050 (EFI 2019). California's policies bear particular significance because of the sheer size of the state's economy. If it were an independent nation, it would have the fifth-largest economy in the world.

Also noteworthy are the ambitious new clean energy requirements for the state of New York, which became law in June 2019. Under the mandate provided by the Climate Leadership and Community Protection Act, New York will have 100\% carbon-free electricity by 2040 and a net-zero carbon economy as a whole by 2050 including sectors such as industry and transportation, which present greater decarbonization challenges than the power sector (Roberts 2019). And other states have also enacted or are considering laws or goals to deeply decarbonize their power sectors or entire economies_-including Colorado, Hawaii, Maine, Minnesota, New Jersey, New Mexico, Oregon, and Washington.

\footnotetext{
${ }^{8}$ State-level interest in clean energy and particularly clean electricity does not always coincide with state leadership that attaches an explicit priority to pro-climate policies. Nor does support for clean energy development align neatly with leadership by the typically more pro-climate Democratic party. The state of Texas, for example, has been a predominantly conservative and petroleumoriented state for years and has had a succession of Republican governors. Nonetheless, Texas is a hotbed of wind power with over $22 \mathrm{GW}$ of installed capacity. In this regard, it would rank sixth in the world if it were an independent nation (Irfan and Zarracina 2019).
} 
Several U.S. states have also introduced legally binding structures that place a price on carbon emissions that are expected to help accelerate the clean energy transition. The California Greenhouse Gas Emissions Cap-and-Trade Program, which was created as a result of the California Global Warming Solutions Act of 2006 (also known as Assembly Bill 32), took effect in 2012 and now covers $85 \%$ of the state's greenhouse gas emissions. It prescribes that 2030 emissions levels should be $40 \%$ below 1990 levels and establishes emissions caps and a quarterly trading system for covered facilities. It is also linked to a similar program in the Canadian province of Quebec (CARB 2019).

Nine northeastern states participate in the Regional Greenhouse Gas Initiative (RGGI)_Connecticut, Delaware, Maine, Maryland, Massachusetts, New Hampshire, New York, Rhode Island, and Vermont-with New Jersey slated to join in 2020 (RGGI 2019). RGGI, which was created in 2009, covers emissions from electricity generating plants with a capacity greater than $25 \mathrm{MW}$. States participating in RGGI have the obligation to create and implement programs to deliver annual power generation emissions reductions of $2.5 \%$ to $2020 .^{9}$

In addition to the electric power sector, certain states have also implemented clean energy policies in the transportation sector, some of which policies interact in complementary fashion with Federal transportation policies, and some of which exist in some tension with policies from Washington, D.C. As an example of the latter, California has a long history of seeking more stringent automobile efficiency standards than those enshrined in the national CAFÉ program.

Since the passage of the Clean Air Act in 1970, California has repeatedly sought, and usually secured, the authority to impose more stringent vehicle standards within the state than are applied elsewhere across the nation, based on the rationale that (a) it had efficiency standards in place before the national program was established, motivated by the state's long struggle with smog, and (b) California's stricter standards protected the state's public health and environment better than the weaker national requirements. Over time, a dozen other states adopted California's more exacting fuel economy standards as well. In 2012, the Obama Administration set in place a package of elevated efficiency standards for passenger cars and light trucks produced from 2017 to 2025, in exchange for which California agreed to harmonize its own regulations with the new Federal requirements. In April 2018, however, the Trump Administration halted the implementation of the Obama package. California brought suit against the Administration, charging it with arbitrary and capricious action. Sixteen other states and the District of Columbia joined that lawsuit, which is still pending as of this writing.

Beyond vehicle efficiency standards, state-level policies for clean transportation have included a wide range of other measures. California and nine other states have established percentage sales targets for so-called "zero-emission vehicles," meaning

\footnotetext{
${ }^{9}$ One facet of both RGGI and the California-Quebec cap-and-trade systems is that to date they have resulted in modest prices per allowance-only \$5.62 per RGGI allowance in June 2019 (RGGI 2019), \$17.45 per California allowance in May 2019 (CARB 2019). Nonetheless, supporters of the two programs claim that they are driving clean energy investments.
} 
battery electric vehicles, hydrogen vehicles, and others with no tailpipe emissions. Numerous states provide preferential treatment on the roads for what have been traditionally referred to as "alternative fueled vehicles," with the benefits including access to high-occupancy lanes on congested roads, or reduced taxes. Some of these benefits have been made available not only to battery electric vehicles or high-efficiency internal combustion vehicles like hybrids, but also to vehicles that simply have the capability to burn part-ethanol fuel, which has given rise to debates over the environmental merits of corn-based ethanol. An increasingly important set of state-level policy interventions has been in the area of charging infrastructure for EVs.

\section{Clean Energy Policies in U.S. Cities}

Just as has been true with a number of U.S. states, many cities and towns have chosen to institute policies to promote the clean energy transition, even though national policy does not currently prioritize that transition. Action by cities carries potential significance because of several factors. For starters, America's urban areas represent between 70 and $80 \%$ of the total population. In addition, many of the decisions that exert significant influence on future emissions occur at local levels.

Land-use patterns reflect local zoning rules, for example, and those rules affect materially considerations such as the degree of urban sprawl, which both spurs individual vehicle use and creates structural challenges for the development of public transit systems. Transportation plans usually are driven by concerns at local levels, although funding usually combines local, state, and Federal resources. On the other hand, many cities lack certain authority, financial power, independent market status, or other attributes needed to implement and sustain effective low-carbon policies. Thus, the role of city-level clean energy policies can be important, but cities do not always have at their disposal all the tools needed to ensure delivery of the desired outcomes.

Municipal-level policies promoting the clean energy transition include some of the same features as state-level policies such as goals for zero-carbon power supply, goals for deep decarbonization by mid-century, and collaborations to signal continuing focus on political commitment. In regard to clean power supply, a growing number of cities and towns have instituted mandates requiring that all electricity be supplied by renewable energy sources. Some of the earliest cities and towns to adopt such policies were modest in size-such as Aspen, Colorado; Burlington, Vermont; and Greensburg, Kansas. More recently, however, many major cities have also adopted municipal clean power supply policies_-including New York, Los Angeles, Washington D.C., and others.

American cities are also employing a wide array of other policies to promote the clean energy transition. These range from the development of sustainable transportation plans and increased efficiency standards for municipal vehicle fleets to energy conservation building codes and efficiency-/climate-related procurement processes 
(such as bulk purchasing arrangements for municipal electric vehicle fleets or for zero-carbon electric power to be used to operate city facilities).

In addition, over 400 U.S. cities and towns representing more than 70 million inhabitants (more than 20\% of the population of the United States) have joined the Mayors' National Climate Action Agenda, also known as the Climate Mayors coalition. Under this effort-initiated in 2014 by Eric Garcetti, the mayor of Los Angeles; Annise Parker, then the mayor of Houston; and Michael Nutter, then the mayor of Philadelphia — cities commit to developing and publicizing near- and longterm climate targets, engaging in peer-to-peer learning, and collaborating on policy development and advocacy. For example, the bipartisan Climate Mayors initiative filed formal statements opposing the Trump Administration's repeal of the Clean Power Plan and its review of the CAFÉ standards for vehicles (Climate Mayors 2019). Many cities also participate in major international groupings of cities such as the Carbon Neutral Cities Alliance and the $\mathrm{C} 40$ grouping. These groups promote exchanges of best practice and advocate for cities' interests on global climate issues, including at the meetings of the Conference of Parties under the UN Framework Agreement on Climate Change.

\section{Geopolitics and the U.S. Clean Energy Transition}

The preceding discussion has outlined the tensions and contradictions that constitute the current state of play in the transition to clean energy within the United States. The reality is one that defies simple, overly broad generalizations: The United States has certainly not achieved broad societal agreement on aggressive reductions in greenhouse gas emissions, especially not at the level of national politics. The divisions are stark, and they are powerful as a political "wedge issue"-a cudgel that can be used by partisan actors to attack opposing leaders. Nonetheless, it is inaccurate to assert that the country is failing entirely to address climate.

Progress has occurred in certain areas, even in the face of the national-level political divisions. The U.S. Congress continues to support scientific and technological research and development in regard to both the operation of the climate system and clean energy technologies that can deliver solutions. Numerous states and cities have made clear that they "are still in" and intend to adhere to emissions cuts pledged by the Obama Administration under the 2015 Paris climate agreement. Moreover, the political sands appear to be shifting slightly at the national level. President Trump has given no indication that he intends to soften his opposition to action on climate. But physical calamities that are thought to be occurring with increasing severity and frequency as a result of a changing climate are afflicting voters more and moreincluding those who have traditionally supported the Republican party. More and more legislators from the President's own party are generating legislative proposals that call for enhanced clean energy research and development, energy efficiency, and even in some rare cases a price on carbon. 
Thus, at present the U.S. transition to clean energy at the national level is characterized by tensions: a mounting sense of urgency on one side, a stubborn denialism on another, and halting steps forward on a third. These tensions seem unlikely to disappear completely over the next decade, but based on the increasing prominence of the climate issue in public policy debates, the country is likely to move along one of two broad paths over the coming decade: Under one path, U.S. policy would continue to be riven by political fragmentation, climate rejectionism, and the resurgent isolationism (including in regard to international climate cooperation) that has flourished during President Trump's tenure. Under an alternative path, the United States would shift to a mode of greater national action - to a sense of purpose and possibility to achieve deep decarbonization by mid-century. These alternative scenarios imply in turn distinct geopolitical implications for the United States and others around the globe, the topic to which we now turn.

A two-way relationship links the U.S. clean energy transition and the world of geopolitics. The timing, extent, and nature of the U.S. transition causes impacts in numerous geopolitical dimensions-including international partners' trust of U.S. leadership and relationships with key partners around the globe.

No less important are links that run in the opposite direction-ways in which geopolitics exert influence on the U.S. clean energy transition. Table 1 summarizes this two-way relationship under two alternative scenarios-one in which the U.S. remains divided and ambivalent in its commitment to clean energy, and the other in which it renews its focus on responding to climate and acts with renewed purpose and commitment.

Several main features emerge from a review of the links between the U.S. clean energy transition and the world of geopolitics. One is that U.S. actions on clean energy and climate seem likely to forge strong impressions around the globe about whether the United States is a heedless contributor to a massive problem or a leading force for solutions. International partners in typically well-heeled settings such as the United Nations and its agencies, the G-7, the G-20, and even the Arctic Council have repeatedly experienced petulant behavior from the Trump Administration. U.S. representatives insisted that climate be given reduced prominence if any at all.

To leaders and voters elsewhere around the world, such a refusal to acknowledge what is a matter of broad scientific consensus, and is an issue with life-or-death implications for some, is wholly inconsistent with the actions of a country that wishes to be influential on the world stage. Thus, continued U.S. reluctance on climate, if that scenario plays out, can reasonably be expected to cause damage to American prestige, soft power, and influence. Less clear, however, is whether any such damage to U.S. prestige would recede into memory if the more favorable scenario occurs and the United States returns to acting with a renewed sense of purpose on climate.

A second geopolitical dimension that merits note is that the posture of the United States on the clean energy transition has major implications for the credibility and effectiveness of international institutions such as the United Nations, and international cooperation in general. The Paris climate agreement, which President Trump declared his desire to leave at the earliest permissible moment, was a triumph of international diplomacy. Its strength lies in its flexibility, its emphasis on differentiated 


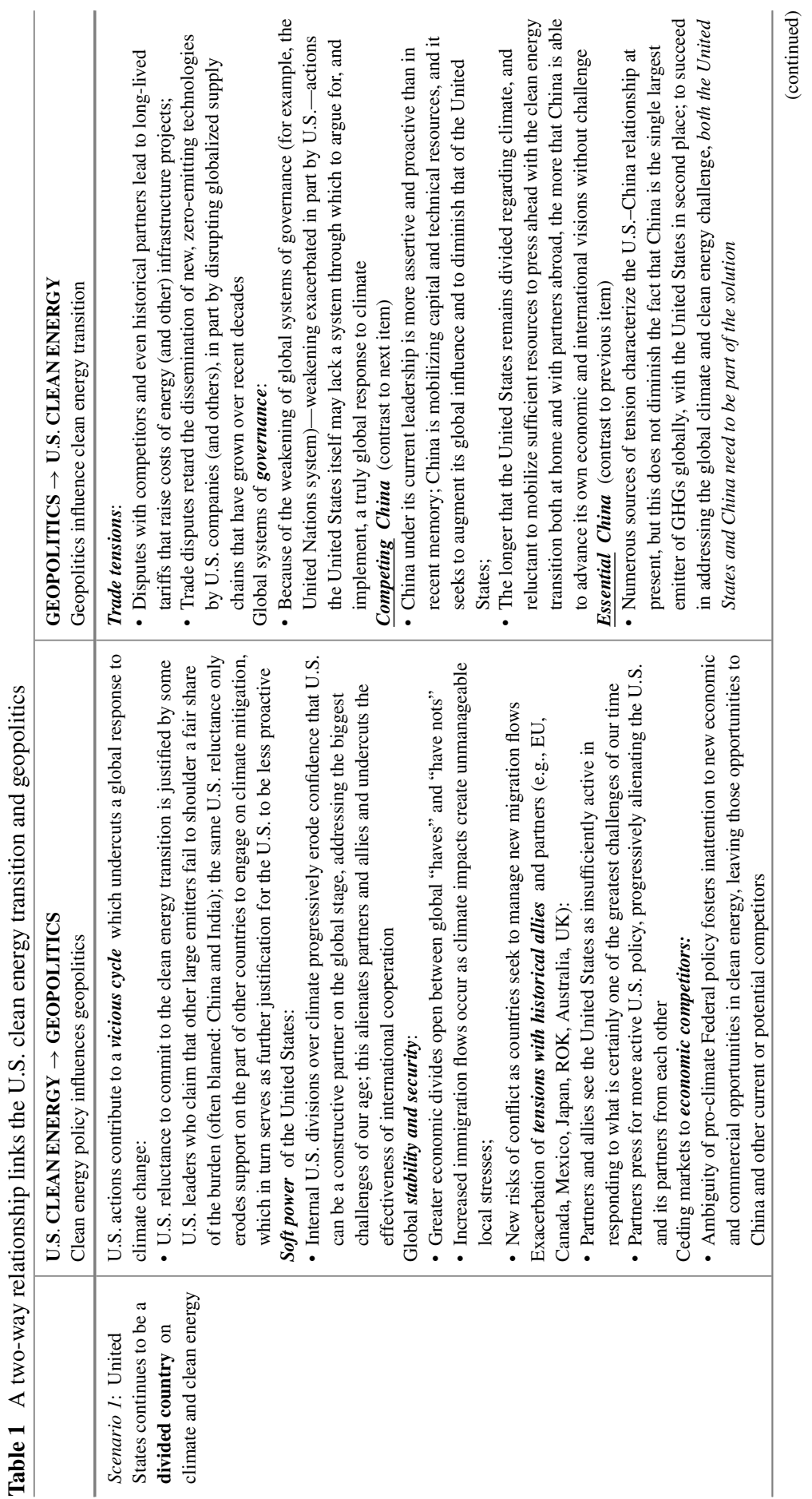




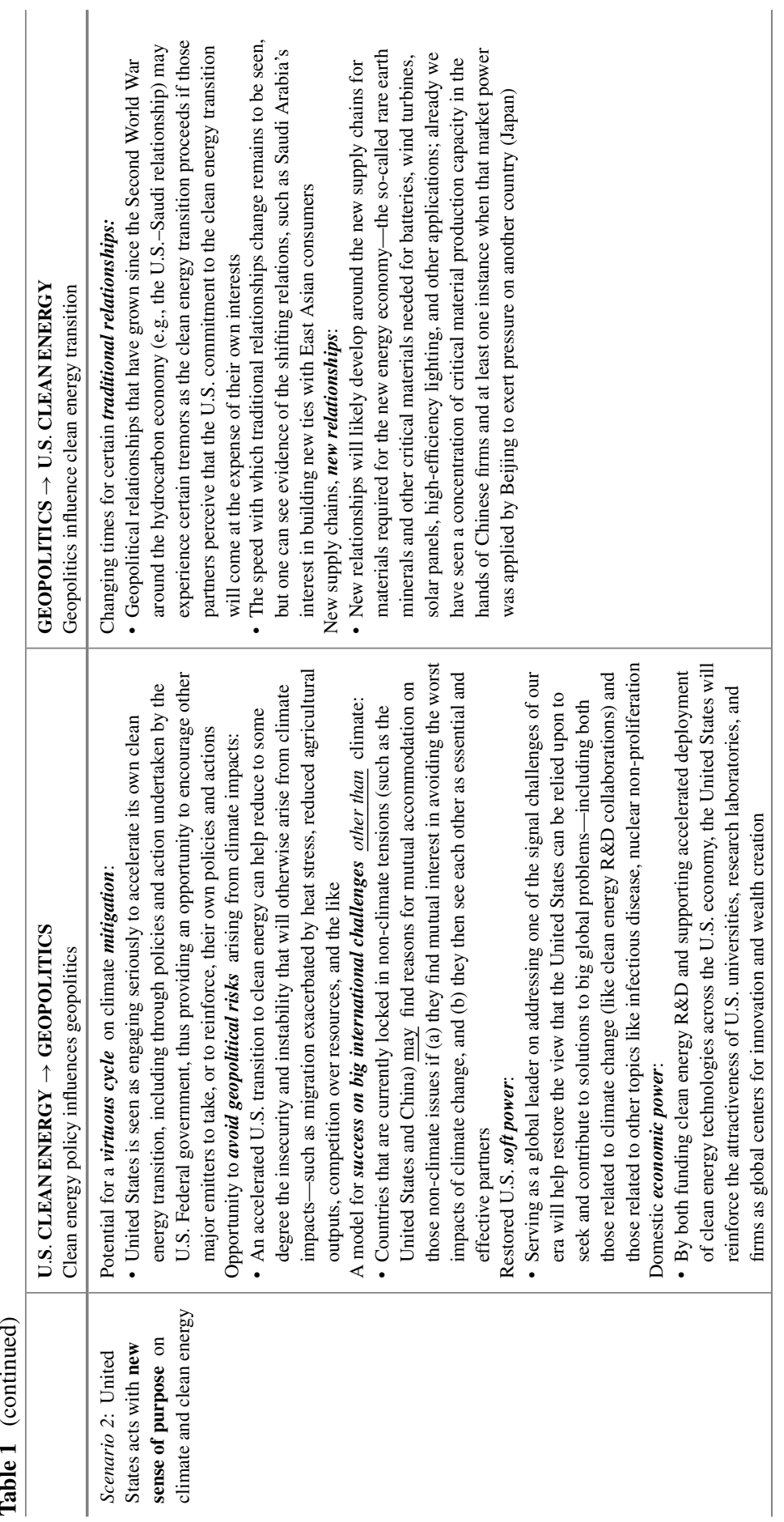


national action, its call for regular assessments of progress, and its ability to marshal momentum for additional action if countries fail to institute sufficiently strong and timely mitigation measures.

Paris embodied critical features for which American negotiators called for years. ${ }^{10}$ Indeed, in several regards, the Paris agreement amounted to a conscious departure from the structures that were agreed in the Kyoto protocol of 1997 and the Copenhagen accord of 2009 (Stern 2018). If the U.S. Federal government not only walked away from the Paris climate agreement but also persisted in its hostility to the very idea of a clean energy transition, this behavior would create ample justification for people around the globe to conclude that the United States cannot be relied upon to play a consistent and constructive role in international cooperation and diplomacy. If on the other hand, the U.S. Federal government returned to the business of providing national and international leadership for the clean energy transition, then solving hard problems would seem to be more within our reach.

A third geopolitical dimension worth highlighting is that the current reluctance of the U.S. Federal government to press ahead with the clean energy transition comes against a particular geopolitical backdrop—an assertive China that is simultaneously a major geopolitical challenge for the United States and also an essential partner in managing the global climate problem. Beijing under President Xi has been exceptionally self-confident and proactive on the global stage. The massive Belt and Road Initiative (BRI), for example, makes available massive amounts of capital that are presently not rivaled by the scale of funds available from the Bretton Woods institutions, bilateral aid programs, or private capital flows. To date, despite declared goals of creating a "green" Belt and Road, the Initiative has instead mobilized billions for coal-fired power plants, which will pollute air and water in the recipient countries and will emit decades worth of carbon dioxide affecting the global climate. Regardless, as long as Washington is inclined toward greater isolationism, budget cuts for development assistance and diplomacy, and Federal inaction on the clean energy transition, the United States will be unable to offer a meaningful alternative for decision-makers in emerging economies. Beijing's development model can mobilize capital quickly, and even if it results in more coal plants, that may be fine from the perspective of some political leaders in certain capitals of the developing world (Elkind 2019).

Just to make the U.S.-China relationship a still more complicated part of the present calculation, China is not just a competitor but also an essential partner in dealing with the global climate problem. No country emits more GHGs than China (26.8\% of total GHG emissions in 2017), but the United States, which represents a much greater share of historical emissions is number two (13.1\% in 2017) (UN Environment 2018). Success therefore requires effective action by both China and the United States to execute the clean energy transition at home, and ideally to

\footnotetext{
${ }^{10} \mathrm{~A}$ number of observers have criticized the Paris agreement for failing to institute binding, topdown reductions in greenhouse gas emissions and penalties for those countries that fail to meet their targets. Nothing short of such stringent requirements, the argument goes, corresponds to the urgency of the climate problem. This view misses entirely the nature of climate change as a "wicked problem," as discussed earlier in this chapter. The climate challenge requires a more nuanced and flexible diplomatic response (Stern 2018).
} 
promote solutions in other countries as well. In the face of ongoing disputes over tariffs, intellectual property protection, technology theft, market access, exchange rates, the South China Sea, economic sanctions, and many other matters, the U.S.China bilateral agenda is overloaded. Nonetheless, the two countries need each other on climate. There is no alternative.

The U.S.-China relationship is not the only one that affects, and is affected by, U.S. decisions about clean energy. The United States has numerous longstanding ties that have been framed in part by U.S. support for rules-based international trade. Some of these relationships may, to some degree, actually suffer if the United States shifts back to a more proactive Federal effort to promote the clean energy transition. Leaders in the oil-producing Gulf Arab states, for example, may worry about whether the United States will remain engaged as a constructive partner for them, invested in their countries' long-term security. ${ }^{11}$ Concerns of this type appear to be encouraging the growth of new relationships, such as the OPEC-Russia relationship and new engagement between Riyadh and Beijing. Even in a world characterized by reduced U.S. importation of traditional fuels (whether as a result of the clean energy transition or simply the last decade's growth in U.S. domestic hydrocarbon production), the United States will continue to have an interest in international trade in goods and services. This reality may limit the extent of change in U.S. relations with the Gulf Arab partners, but some change is afoot regardless.

A final geopolitical consideration that could arise from U.S. policies on the clean energy transition relates to materials required for production of low-carbon energy systems. Analysts and policy-makers have recognized for some time that clean energy technologies rely on a number of critical materials whose supply chains are not very diversified (DOE 2011). Indeed, concerns have arisen because the predominant supply of a number of those materials is controlled by Chinese companies, and China attempted to exploit that dominance in 2010 after a fishing dispute with Japan (Bradsher 2010). As the United States and other economies proceed with the clean energy transition, their ability to deploy cost-effectively energy-efficient lighting, wind and solar generating plants, batteries, and other technologies will require adequate and assured supply chains for critical materials. This does not mean automatically that problems will arise with the availability of critical materials; new supplies, innovation, and re-use may all help to alleviate any shortages. But the transition to clean energy will nonetheless place in the spotlight a new set of supply relationships that will need to be managed effectively.

\footnotetext{
${ }^{11}$ A further complication: The very same Gulf Arab states, where some leaders worry about a potential reduced long-term U.S. commitment to the region, are among those countries with the most to lose as median temperatures rise. For an excellent discussion of climate change vulnerability in the Gulf, see Krane (2019). In this case, the links between geopolitics and the clean energy transition amount to a situation in which geopolitical strains may arise from either action or inaction on clean energy and climate.
} 


\section{Conclusions}

Especially since the end of the Second World War, the United States has played a major role on the geopolitical stage. It has sought to influence the rules that governed international trade, global financial systems, security interests, and even environmental standards. The issue of climate change presents an unparalleled challenge to the postwar global order because the roots of global warming run so deep in how we conduct our daily lives and operate our economies. To address this "wicked problem" requires unprecedented ingenuity, dedication, and persistence. It requires policies at all levels of governance that combine speed, scale, and durability.

To date, unfortunately, the very country that has played such an important geopolitical role since the middle of the last century has not demonstrated clear and consistent leadership when it comes to climate. To be sure, especially during the Trump presidency, leaders at the state and municipal levels across the United States have signaled a progressively greater willingness to act on the climate problem. At the national level, however, the political leadership of the United States remains divided. There is a possibility that the United States is approaching a turning point from which there could emerge a restored national focus on solutions for clean energy and climate. An alternative option, however, is that the United States continues to struggle to find a unified voice on these matters.

If climate change is indeed one of the defining issues of our day, then the geopolitical implications of the U.S. clean energy transition are hard to exaggerate. Without American climate leadership, it is hard to imagine global success in responding adequately, and in this scenario American standing on the world stage will be significantly diminished. With American leadership, one can imagine the possibility of success in responding to the threat of climate change. But the hour is late, and indecision by U.S. political leaders is already taking a toll on American interests on the global stage.

\section{References}

Adler D (2019) U.S. climate change litigation in the age of trump: year two. Sabin Center for Climate Change Law, Columbia Law School. http://columbiaclimatelaw.com/files/ 2019/06/Adler-2019-06-US-Climate-Change-Litigation-in-Age-of-Trump-Year-2-Report.pdf? utm_source=newsletter\&utm_medium=email\&utm_campaign=newsletter_axiosgenerate\& stream=top. Accessed 1 July 2019

Alvarez RA, Zavala-Ariaza D, Lyon D, Allen D, Barkley Z, Brandt A, Davis K, Herndon S, Jacob D, Karion A, Kort D, Lamb B, Lauvaux T, Maasakkers J, Marchese A, Omara M, Pacala S, Peischl J, Robinson A, Shepson P, Sweeney C, Townsend-Small A, Wofsy S, Hamburg S (2018) Assessment of methane emissions from the U.S. oil and gas supply chain. Science 361:186-188. https://science.sciencemag.org/content/361/6398/186. Accessed 2 July 2019

America's Pledge Initiative on Climate (2018) Fulfilling America's pledge: how states, cities, and businesses are leading the united states to a low-carbon future. https://www. americaspledgeonclimate.com/fulfilling-americas-pledge/. Accessed 2 July 2019 
Australian Public Service Commission (2007) Tackling wicked problems: a public policy perspective. https://www.apsc.gov.au/publications-and-media/archive/publications-archive/ tackling-wicked-problems. Accessed 25 June 2019

Barbose G (2018) U.S. renewable portfolio standards: 2018 annual status report. Lawrence Berkeley National Laboratory. http://eta-publications.lbl.gov/sites/default/files/2018_annual_ rps_summary_report.pdf. Accessed 2 July 2019

Bordoff J (2019) Getting real about the green new deal. Democracy. J Ideas. https:// democracyjournal.org/arguments/getting-real-about-the-green-new-deal/. Accessed 3 July 2019

Bradsher K (2010) Amid tension, China blocks vital exports to Japan. New York Times. https:// www.nytimes.com/2010/09/23/business/global/23rare.html. Accessed 5 July 2019

California Air Resources Board (2019) Cap and trade program (website). https://www.arb.ca.gov/ cc/capandtrade/capandtrade.htm. Accessed 3 July 2019

Center on Global Energy Policy (2019) Prospects for climate solutions - February 6, 2019 event video. https://energypolicy.columbia.edu/events-calendar/prospects-climate-solutions. Accessed 3 July 2019

Climate Mayors website (2019). http://climatemayors.org. Accessed 3 July 2019

Congressional Budget Office (2009) Cost estimate - HR 2454, American clean energy and security act of 2009. https://www.cbo.gov/sites/default/files/111th-congress-2009-2010/costestimate/ hr24541.pdf. Accessed 11 July 2019

Database of State Incentives for Renewables and Efficiency (2019) Renewables \& clean energy standards, June 2019. North Carolina Clean Energy Technology Center. https://s3.amazonaws.com/ ncsolarcen-prod/wp-content/uploads/2019/06/RPS-CES-June2019.pdf. Accessed 2 July 2019

Elkind J (2019) Toward a real green belt and road. Center on Global Energy Policy, Columbia University. https://energypolicy.columbia.edu/sites/default/files/file-uploads/Real\%20Green\%20Belt\% 20and\%20Road_CGEP_Report_042219_Final.pdf. Accessed 2 July 2019

Energy Futures Initiative (2019) Optionality, flexibility, and innovation: pathways for deep decarbonization in California. https://static1.squarespace.com/static/58ec123cb3db2bd94e057628/t/ 5ced7013ee6eb03a466f546d/1559064604282/EFI_CA_Decarbonization_SFPM.pdf. Accessed 2 July 2019

Energy Information Administration (2018) Oil: crude and petroleum products explained - use of oil (updated 28 September 2018). https://www.eia.gov/energyexplained/index.php?page=oil_use. Accessed 1 July 2019

Energy Information Administration (2019a) Annual energy outlook 2019. https://www.eia.gov/ outlooks/aeo/. Accessed 26 June 2019

Energy Information Administration (2019b) Today in energy: in 2018, the United States consumed more energy than ever before, 16 April 2019. https://www.eia.gov/todayinenergy/detail.php?id= 39092. Accessed 1 July 2019

Federal Highway Administration (2018) Travel monitoring: historical monthly VMT report (modified 26 April 2018). https://www.fhwa.dot.gov/policyinformation/travel_monitoring/ historicvmt.cfm. Accessed 1 July 2019

Friedman L (2019) EPA finalizes its plan to replace Obama-Era climate rules. New York Times. https://www.nytimes.com/2019/06/19/climate/epa-coal-emissions.html. Accessed 1 July 2019

Gustin G (2018) Climate denial pervades the trump white house, but it's hitting some limits. Inside Climate News, 8 January 2018. https://insideclimatenews.org/news/08012018/climatechange-denial-trump-hoax-2017-year-review-pruitt-tillerson-endangerment-finding. Accessed 1 July 2018

Houser T, Marsters P, Rhodium Group (2018) Final U.S. emissions numbers for 2017, 29 March 2018. https://rhg.com/research/final-us-emissions-numbers-for-2017/. Accessed 29 June 2019

Intergovernmental Panel on Climate Change (2018) Special report: global warming of $1.5^{\circ} \mathrm{C}$ - summary for policymakers. https://www.ipcc.ch/2018/10/08/summary-for-policymakers-ofipcc-special-report-on-global-warming-of-1-5c-approved-by-governments/. Accessed 26 June 2019 
Irfan U and Zarracina J (2019) 4 maps that show who's being left behind in America's wind-power boom. Vox, 14 June 2019. https://www.vox.com/energy-and-environment/2018/5/2/17290880/ trump-wind-power-renewable-energy-maps. Accessed 2 July 2019

Kaufman N and Gordon K (2018) The energy, economic, and emissions implications of a federal U.S. carbon tax. https://energypolicy.columbia.edu/sites/default/files/pictures/CGEP_ SummaryOfCarbonTaxModeling.pdf. Accessed 26 June 2019

Krane J (2019) Energy kingdoms: oil and political survival in the Persian Gulf. Columbia University Press, New York, pp 160-172

McNutt M, Mote CD Jr, and Dzau VJ (2019) National Academies Presidents affirm the scientific evidence of climate change. National Academies of Science, Engineering, and Medicine, 18 June 2018. http://www8.nationalacademies.org/onpinews/newsitem. aspx?RecordID=06182019. Accessed 25 June 2019

National Association of State Energy Officials (NASEO) and Energy Future Initiative (EFI) (2019). The 2019 U.S. energy and employment report. https://www.usenergyjobs.org/2019report. Accessed 7 October 2019

National Conference of State Legislatures (2019) State renewable portfolio standards and goals, 1 February 2019. http://www.ncsl.org/research/energy/renewable-portfolio-standards. aspx. Accessed 2 July 2019

Perry R, Zinke R, Pruitt S (2017) Paving the path to U.S. energy dominance. Washington Times, 26 June 2017. https://www.washingtontimes.com/news/2017/jun/26/us-energy-dominance-isachievable/. Accessed 16 May 2018

Phillip A (2017) Mulvaney defends proposed cuts to climate research and poverty programs, deeming them wasteful or ineffective. Washington Post, 16 March 2017. https://www.washingtonpost. com/news/post-politics/wp/2017/03/16/mulvaney-defends-proposed-cuts-to-climate-researchpoverty-programs-deeming-them-wasteful-or-ineffective/?utm_term $=.35976682 \mathrm{f} 1 \mathrm{ac}$. Accessed 1 July 2019

Pyper J (2019) US electric vehicle sales increased by $81 \%$ in 2018. GreenTech Media, 7 January 2019. https://www.greentechmedia.com/articles/read/us-electric-vehicle-sales-increase-by81-in-2018\#gs.ohnerc. Accessed 11 July 2019

RGGI Inc. (2019) RGGI states welcome New Jersey as its CO2 regulation is finalized (press release - 17 June 2019). https://www.rggi.org/sites/default/files/Uploads/Press-Releases/2019_06_17_ NJ_Announcement_Release.pdf. Accessed 3 July 2019

Roberts D (2019) New York just passed the most ambitious climate target in the country. Vox, 20 June 2019. https://www.vox.com/energy-and-environment/2019/6/20/18691058/new-yorkgreen-new-deal-climate-change-cuomo. Accessed 2 July 2019

Stern T (2018) The Paris agreement and its future. Brookings Institution. https://www.brookings. edu/wp-content/uploads/2018/10/The-Paris-Agreement-and-Its-Future-Todd-Stern-October2018.pdf. Accessed 5 July 2019

United Nations Environment Programme (2018) Emissions gap report 2018. https://www. unenvironment.org/resources/emissions-gap-report-2018. Accessed 29 June 2019

United States Climate Alliance (2019a) 2019 fact sheet. https://static1.squarespace.com/static/ 5a4cfbfe18b27d4da21c9361/t/5ccb5aa56e9a7f542fe4233c/1556830885910/USCA+Factsheet_ April+2019.pdf. Accessed 2 July 2019

United States Climate Alliance (2019b) Montana Governor Steve bullock becomes 25th governor to join U.S. climate alliance (press release 1 July 2019). https://www.usclimatealliance. org/publications/2019/7/1/montana-governor-steve-bullock-becomes-25th-governor-to-join-usclimate-alliance. Accessed 2 July 2019

United States House of Representatives (2019) H.Res. 109 - recognizing the duty of the Federal government to create a Green New Deal. https://www.congress.gov/bill/116th-congress/houseresolution/109/text. Accessed 3 July 2019

U.S. Department of Energy (2011) Critical materials strategy, December 2011. https://www.energy. gov/sites/prod/files/2016/12/f34/2011\%20Critical\%20Materials\%20Strategy\%20Report.pdf. Accessed 5 July 2019 
U.S. Department of Energy (2017) FY 2018 congressional budget request - budget in brief. https://www.energy.gov/sites/prod/files/2017/05/f34/FY2018BudgetinBrief_3.pdf. Accessed 1 July 2019

U.S. Department of Energy (2018) FY 2019 budget justification. https://www.energy.gov/sites/prod/ files/2018/04/f50/FY2019ControlTablebyAppropriation.pdf. Accessed 1 July 2019

U.S. Department of Energy (2019) FY 2020 budget justification. https://www.energy.gov/cfo/ downloads/fy-2020-budget-justification. Accessed 1 July 2019

White House (2013) The President's climate action plan, June 2013. https://obamawhitehouse. archives.gov/sites/default/files/image/president27sclimateactionplan.pdf. Accessed 1 July 2019

White House (2016a) Fact sheet: the recovery act made the single largest investment in clean energy in history, driving the deployment of clean energy, promoting energy efficiency, and supporting manufacturing, 25 February 2016. https://obamawhitehouse.archives.gov/the-press-office/2016/ 02/25/fact-sheet-recovery-act-made-largest-single-investment-clean-energy. Accessed 1 July 2019

White House (2016b) United States mid-century strategy for deep decarbonization. https://unfccc. int/files/focus/long-term_strategies/application/pdf/mid_century_strategy_report-final_red.pdf. Accessed 1 July 2019

Open Access This chapter is licensed under the terms of the Creative Commons Attribution 4.0 International License (http://creativecommons.org/licenses/by/4.0/), which permits use, sharing, adaptation, distribution and reproduction in any medium or format, as long as you give appropriate credit to the original author(s) and the source, provide a link to the Creative Commons license and indicate if changes were made.

The images or other third party material in this chapter are included in the chapter's Creative Commons license, unless indicated otherwise in a credit line to the material. If material is not included in the chapter's Creative Commons license and your intended use is not permitted by statutory regulation or exceeds the permitted use, you will need to obtain permission directly from the copyright holder. 